\title{
Relationship between Grain Yield and Agronomic Traits in Winter Barley
}

\author{
Milan Mirosavljević $\cdot$ Novo Pržulj $\cdot$ Petar Čanak $\cdot$ Vojislava Momčilović $\cdot$ \\ Vladimir Aćin · Bojan Jocković · Nikola Hristov • Novica Mladenov
}

\begin{abstract}
Summary: Grain yield is one of the most important and complex traits in cereal breeding and depends upon a combination of different plant traits. Therefore, an effective breeding program requires a proper understanding of the relationships between grain yield and agronomic traits. The objectives of this study were the evaluation of tworowed winter malting barley genotypes and the perceiving of relationships among grain yield and their agronomic and quality traits. The trials with 19 two-rowed winter malting barley genotypes were conducted during three years. The relationships among plant lodging, height, thousand kernel weight, hectolitre mass, grain protein content and grain yield, were studied by PCA biplot analysis. The results showed that the influence of year, genotype and genotype by year interaction on barley grain yield were significant. Further, results indicate that two-rowed winter malting barley grain yield can be improved by selecting plants of average plant height with thousand kernel weight above $41.0 \mathrm{~g}$ and grain protein content of about $11.0 \mathrm{~g} 100^{-1} \mathrm{~g} \mathrm{dm}$.

Keywords: agronomic traits, barley, biplot, genotype, grain yield, Hordeum vulgare, PCA, quality
\end{abstract}

\section{Introduction}

Barley (Hordeum vulgare L.) is one of the most important small-grained cereal crops, placing fourth in world cereal production, after maize, rice and wheat (FAOSTAT 2014). In Serbia, barley production occupies between 90,000 and 100,000 ha across the country and it is used for livestock feed, malt, food and seed production (FAOSTAT 2014). Climate conditions in the Pannonian plain show large and unpredictable variations across different cropping seasons (Pržulj \& Momčilović 2012). Moreover, Olesen et al. (2011) predict that climate change will increase the occurrence of undesirable years for crop production. As a response to these changeable environmental conditions, it is necessary to define selection objectives and identify a winter barley ideotype which would be used as a model for the creation of new advanced cultivars. The barley ideotype should possess good tolerance to drought and harsh winter conditions and additionally tolerate variations and extremes in temperature and precipitation. The ideotype should also be suited

M. Mirosavljević* · P. Čanak · V. Momčilović · V. Aćin · B. Jocković $\cdot$ N. Hristov $\cdot$ N. Mladenov

Institute of Field and Vegetable Crops, 30 Maksima Gorkog, 21000 Novi Sad, Serbia

e-mail:milan.mirosavljevic@nsseme.com

N. Pržulj

University of Banja Luka, Faculty of Agriculture, Bul. vojvode Petra Bojovića1A, Banja Luka, Republic of Srpska, 78000, Bosnia and Herzegovina to diverse conditions of cultivation (Rasmusson 1987).

Modern barley breeding is largely directed towards the development of genotypes characterized with increased yield potential, wide adaptation and high responses to agronomic inputs (Pržulj et al. 2014). Although yield is the universal breeding objective, an effective breeding programme requires a proper understanding of the essential traits and the relationships among them (Yan \& Kang 2003). Several agronomic and technological traits such as lodging (LOG), plant height $(\mathrm{PH})$, thousand kernel weight (TKW), hectolitre mass $(\mathrm{HM})$ and grain protein content (GPC) have significant influence on barley grain yield and quality. LOG is a major constraint limiting the yield and quality of barley (Jedel \& Helm 1991). Certain plant characteristics such as long and thin stems and excessive vegetative growth make plants susceptible to lodging. Despite the fact that HM and TKW have lost significance in the past decades, they are still important indicators of barley quality. TKW has a positive relationship with starch content which is desirable for brewers since it is a source of fermentable sugars (Savin \& Molina-Cano 2002). Furthermore, numerous recent studies found positive relationship between $\mathrm{HM}$ and malt and feed quality (Fox et al. 2006, Fox et al. 2007).

Acknowledgements: This paper presents the results of the project TR-31066 "Modern breeding of small grains for present and future needs", supported by the Ministry of Education, Science and Technological Development of the Republic of Serbia. 
Considering the presence of reverse correlation between GPC and malt extract, GPC is one of the most important traits influencing malt quality (Wright 2000). Often as result of the competition for photo-assimilates, increase of one trait tends to be followed by change in other trait (Slafer et al. 1996), and therefore, it is necessary to correctly understand interrelationships between them.

Different statistical analysis, such as correlation, path coefficient and principal component analysis (PCA) can be used to reveal associations between yield and other agronomic traits. PCA has been widely used in plant sciences for reducing variables and grouping genotypes (Eticha et al. 2010). This method has been exploited to identify trait interrelationships in different varieties of spring barley (Žáková \& Benková 2006), maize (Kamara et al. 2003) and wheat (Mladenov et al. 2012).

The objective of this study was the evaluation of winter two-rowed malting barley genotypes across three growing seasons and assessing the relations among their agronomic and quality traits.

\section{Materials and Methods}

The genetic material for this study consisted of 19 two two-rowed winter malting barley genotypes (G1G19) developed at the Institute of Field and Vegetable Crops, Novi Sad, Serbia (Tab. 1). The experimental plot size was $5 \mathrm{~m}^{2}$, with the sowing rate of 400 kernels per $\mathrm{m}^{2}$. The plots were $1.0 \mathrm{~m}$ wide and $5 \mathrm{~m}$ long, with $0.1 \mathrm{~m}$ spacing between rows. The trials were conducted during three growing seasons (2009/10, 2010/11 and 2011/12), arranged in randomized complete block design with three replications, at Rimski Šančevi experimental field near Novi Sad $\left(45^{\circ} 20^{\prime} \mathrm{N}\right.$ and $19^{\circ}$ $\left.51^{\prime} \mathrm{E}\right)$. Standard agricultural practices were applied in all trial seasons.

Table 1. Genotype abbreviation, pedigrees of the tested genotypes and relative maturity

\begin{tabular}{|c|c|c|}
\hline $\begin{array}{l}\text { Genotype } \\
\text { abbr. }\end{array}$ & Pedigree & $\begin{array}{l}\text { Relative } \\
\text { maturity }\end{array}$ \\
\hline G1 & Irla/Novosadski 525 & $\mathrm{E}$ \\
\hline G2 & Posanee/NS 523 & $\mathrm{ME}$ \\
\hline G3** & 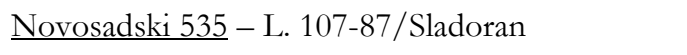 & $\mathrm{ME}$ \\
\hline G4 & Belivia/Novosadski 525 & ME \\
\hline G5 & Novosadski 525/Sonja & ME \\
\hline G6 & Astrid/ Novosadski 529 & ME \\
\hline G7 & Novosadski 333/Alpha & ML \\
\hline G8 & Sonate/Novosadski 331 & $\mathrm{~L}$ \\
\hline G9** & 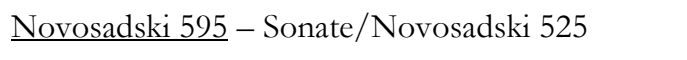 & $\mathrm{E}$ \\
\hline G10 & Korten/Novosadski 293// Novosadski 525 & ML \\
\hline G11 & Rex/3/Astrid/Novosadski529//Novosadski 525 & $\mathrm{E}$ \\
\hline G12 & Obzor/Novosadski 293//Novosadski 519 & $\mathrm{ME}$ \\
\hline G13 & Novosadski 331/Sonate & ML \\
\hline G14 & Novosadski 331/Amethyst & $\mathrm{ME}$ \\
\hline G15 & NS 509/Alpha & $\mathrm{E}$ \\
\hline G16 & Novosadski 525/Jagodinac & ML \\
\hline G17 & Alpha/Astrid//Sladoran & $\mathrm{ME}$ \\
\hline G18 & Marylin/Sonate//NS 541 & ME \\
\hline G19 & NS 507/Vanesa//Boreale & ML \\
\hline
\end{tabular}

*E, early; ME, medium early; ML, medium late; ** standard variety 
The severity of LOG (\%) was recorded as a percentage of the plot lodged at the stage of anthesis. TKW (g) was determined from measuring three sets of 300 grains per plot and expressed as the weight of 1000 grains. HM (kg hl-1) was determined by measuring a known volume of the natural seed sample. Grain nitrogen concentration was obtained by Kjeldahl analysis and GPC expressed on dry weight basis was estimated by multiplying grain $\mathrm{N}$ by 6.25 (Yuen et al. 1953). YLD ( $\mathrm{t} \mathrm{ha}^{-1}$ ) was determined for combine-harvested plots in each of the three replications. Moisture content was determined using a grain analysis computer (Model GAC2100, DickeyJohn, Auburn, IL) and grain yield was corrected to $140 \mathrm{~g} \mathrm{~kg}^{-1}$ moisture.

Data were processed using two-way analysis of variance, with software STATISTICA 10. Means were compared using Duncan's multiple range test (Steel \& Torrie 1980). Principal component analysis (PCA) was used to determine interdependence between the traits.

\section{Results and Discussion}

This study showed that the year $(\mathrm{Y})$ was mainly responsible for variation of studied traits (LOG, PH, $\mathrm{HM}$ and YLD) in two-rowed winter malting barley (Tab. 2). Further, genotype $(G)$ and genotype by year interaction $(\mathrm{G} \times \mathrm{Y})$ effects explained the highest percent of TKW and GPC variations, respectively.

In Table 3 LOG, PH, TKW, HM, GPC and YLD means for the 19 genotypes across three growing seasons are presented. Duncan's test showed existence of significant difference between these means in all examined traits $(p<0.01)$. The highest lodging rate was observed in the 2009/10 growing season. Among tested genotypes, G1 was resistant, while G8 was susceptible to LOG. In PH, $84.1 \%$ of total variation was accounted for by $\mathrm{Y}$ effect and their interactions with G. According to different authors (Pržulj et al. 2010, Gholipoor et al. 2013), optimum $\mathrm{PH}$ for modern barley cultivars ranges from $90-105$ $\mathrm{cm}$. Across years and genotypes, average $\mathrm{PH}$ value of $100.9 \mathrm{~cm}$ was within this range. Genotype G12 had the highest average PH, while G17 had the lowest one. Across growing seasons, genotypes G4, G10 and G19 had the highest TKW, while the lowest TKW was recorded in G18. As reported by Pržulj et al. (2014), cultivars with medium-sized grains (41-44 g) are more suitable for malting, because they soak uniformly and rapidly. Average genotype HM across years varied from 73.4-76.6 $\mathrm{kg} \mathrm{hl}^{-1}$, with G19 showing the highest value.

Due to the presence of the high $G \times E$ interaction, one genotype can have low GPC in one year and high GPC in another (data not shown), which complicates selection of barley genotypes with desirable GPC (Falconer \& Mackay 1966). The permitted range of GPC for production of European lager beer ranges from 9.5 to $11.5 \%$ (Pettersson \& Eckerster 2007). Accordingly to this range, G6, G11, G13, G14 and G15 are not suitable for beer production, and they should be excluded from further malting barley trials and redirected to feed production.

More than half of the variation in barley YLD was under the effect of Y $(57 \%)$, while $G$ explained one fifth of variation $(21 \%)$. High percentage of total variation explained by $\mathrm{Y}$ indicates that climate conditions varied considerably between different seasons. The genotypes G4, G10 and G19 had the highest, and G8 had the lowest YLD across the years. Across cultivars, the lowest YLD value was recorded in 2009/10 and the highest in 2010/11.

Table 2. ANOVA mean squares and percentage of variance components for lodging (LOG), plant height $(\mathrm{PH})$, thousand kernel weight (TKW), hectolitre mass (HM), grain protein content (GPC) and grain yield (YLD)

\begin{tabular}{|c|c|c|c|c|c|c|c|}
\hline $\begin{array}{l}\text { Source of } \\
\text { variation }\end{array}$ & $\mathrm{df}$ & $\begin{array}{c}\text { LOG } \\
(\%)\end{array}$ & $\mathrm{PH}(\mathrm{cm})$ & TKW (g) & $\begin{array}{c}\mathrm{HM} \\
\left(\mathrm{kg} \mathrm{hl}^{-1}\right)\end{array}$ & $\begin{array}{c}\text { GPC } \\
\left(\mathrm{g} 100^{-1} \mathrm{~g} \mathrm{dm}\right)\end{array}$ & $\begin{array}{l}\text { YLD } \\
\left(\mathrm{t} \mathrm{ha}^{-1}\right)\end{array}$ \\
\hline G & 18 & $405.72^{* *}$ & $39.63^{* *}$ & $41.51^{* *}$ & $9.92 * *$ & $2.34 * *$ & $2.39 * *$ \\
\hline Y & 2 & $61486.78^{* *}$ & $3687.98^{* *}$ & $157.94 * *$ & $585.42^{* *}$ & $15.93^{* *}$ & $58.32^{* *}$ \\
\hline$G \times Y$ & 36 & $390.13 * *$ & $27.33^{* *}$ & $15.50 * *$ & $8.29 * *$ & $1.18^{* *}$ & $1.01 * *$ \\
\hline Residual & 114 & $42.19 * *$ & $7.64 * *$ & $0.26^{* *}$ & $0.26^{* *}$ & $0.04 * *$ & $0.08^{* *}$ \\
\hline \multicolumn{8}{|l|}{$\begin{array}{l}\% \text { of } \\
\text { variation }\end{array}$} \\
\hline G & & 4.90 & 7.17 & 45.25 & 10.64 & 34.70 & 21.00 \\
\hline $\mathrm{Y}$ & & 82.46 & 74.17 & 19.13 & 69.79 & 26.24 & 57.00 \\
\hline$G \times Y$ & & 9.42 & 9.89 & 33.81 & 17.79 & 35.04 & 17.71 \\
\hline
\end{tabular}

\footnotetext{
** significant at 0.01 probability level
} 
Table 3. Average values of lodging (LOG), plant height (PH), thousand kernel weight (TKW), hectolitre mass (HM), grain protein content (GPC) and grain yield (YLD) in 19 advanced barley genotypes

\begin{tabular}{|c|c|c|c|c|c|c|}
\hline Genotype & LOG $(\%)$ & $\mathrm{PH}(\mathrm{cm})$ & TKW (g) & $\begin{array}{c}\mathrm{HM} \\
\left(\mathrm{kg} \mathrm{h}^{-1}\right)\end{array}$ & $\begin{array}{c}\text { GPC } \\
\left(\mathrm{g} 100^{-1} \mathrm{~g} \mathrm{dm}\right)\end{array}$ & $\begin{array}{l}\text { YLD } \\
\left(\mathrm{t} \mathrm{ha}^{-1}\right)\end{array}$ \\
\hline G1 & $16.7 \mathrm{~g}$ & $98.0^{\mathrm{gh}}$ & $42.2^{\mathrm{d}}$ & $75.5^{\mathrm{cd}}$ & 11.1 ghi & $9.14 \mathrm{bcd}$ \\
\hline G2 & 33.9abc & $104.0^{\mathrm{ab}}$ & $42.8^{\mathrm{bc}}$ & $74.9^{\mathrm{e}}$ & $10.1^{1}$ & $8.38^{\mathrm{hi}}$ \\
\hline G3 & 23.9 def & 99.9 defgh & $38.7 \mathrm{gh}$ & $75.3^{\text {cde }}$ & $11.4^{\mathrm{e}}$ & $8.74^{\mathrm{ef}}$ \\
\hline G4 & $28.9 \mathrm{~cd}$ & $101.2^{\mathrm{bcdef}}$ & $43.5^{\mathrm{a}}$ & $76.1^{\mathrm{b}}$ & $11.2^{\mathrm{fgh}}$ & $9.58^{a}$ \\
\hline G5 & $25.2^{\mathrm{def}}$ & $98.5^{\mathrm{fgh}}$ & $39.9^{\mathrm{f}}$ & $75.0^{\mathrm{de}}$ & $11.3^{\mathrm{efg}}$ & $9.27 \mathrm{bc}$ \\
\hline G6 & $30.8^{\mathrm{cd}}$ & 101.6bcde & $41.2^{\mathrm{e}}$ & $73.6^{\mathrm{fgh}}$ & $11.7^{\mathrm{d}}$ & $9.27 \mathrm{bc}$ \\
\hline G7 & $37.7^{\mathrm{ab}}$ & 101.4bcdef & $40.0^{\mathrm{f}}$ & $73.4^{\mathrm{h}}$ & $11.0^{\mathrm{hij}}$ & $8.61^{\mathrm{fgh}}$ \\
\hline G8 & $39.6^{a}$ & 101.4bcdef & 35.8 & $73.6^{\text {fgh }}$ & $11.0 \mathrm{ijk}$ & 7.78 \\
\hline G9 & $21.7^{\mathrm{efg}}$ & $100.4^{\text {cdefgh }}$ & $41.5^{\mathrm{e}}$ & $74.1^{\mathrm{f}}$ & $10.9^{\mathrm{jk}}$ & $8.96^{\mathrm{de}}$ \\
\hline G10 & $15.6^{\mathrm{g}}$ & $98.5^{\mathrm{fgh}}$ & $43.5^{\mathrm{a}}$ & $76.08^{\mathrm{b}}$ & 11.1 ghi & $9.62^{\mathrm{a}}$ \\
\hline G11 & $24.9 \mathrm{def}$ & 103.0abc & $42.2^{\mathrm{d}}$ & $76.6^{a}$ & $12.4^{a}$ & $9.43^{\mathrm{ab}}$ \\
\hline G12 & $29.6^{\mathrm{cd}}$ & $105.0^{\mathrm{a}}$ & $41.3^{\mathrm{e}}$ & $75.2^{\text {cde }}$ & $11.2^{\mathrm{fgh}}$ & 8.49ghi \\
\hline G13 & $28.3^{\text {cde }}$ & $102.2^{\mathrm{abcd}}$ & $40.4^{\mathrm{f}}$ & $75.7 \mathrm{bc}$ & $12.0^{\mathrm{b}}$ & $8.50^{\text {fghi }}$ \\
\hline G14 & $32.8 \mathrm{bc}$ & 99.1 efgh & $42.4 \mathrm{~cd}$ & 75.0de & $11.8^{\mathrm{d}}$ & $9.03 \mathrm{~cd}$ \\
\hline G15 & $38.0 \mathrm{ab}$ & 102.0abcde & $39.1 \mathrm{~g}$ & 75.3 cde & $11.9 \mathrm{bc}$ & $8.72^{\mathrm{efg}}$ \\
\hline G16 & $27.8^{\text {cdef }}$ & $103.5^{\mathrm{ab}}$ & $41.3^{\mathrm{e}}$ & $73.9 \mathrm{fgh}$ & 11.1 ghi & $8.30^{\mathrm{i}}$ \\
\hline G17 & 26.9 cdef & $97.4^{\mathrm{h}}$ & $38.3^{\mathrm{h}}$ & $74.1^{\mathrm{fg}}$ & $10.8 \mathrm{k}$ & $9.39 \mathrm{ab}$ \\
\hline G18 & $30.7 \mathrm{~cd}$ & $99.8^{\text {defgh }}$ & $37.6^{\mathrm{i}}$ & $73.6 \mathrm{gh}$ & $11.4^{\mathrm{ef}}$ & 8.69efg \\
\hline G19 & $20.9 \mathrm{fg}$ & $100.9^{\text {bcdefg }}$ & $43.2^{\mathrm{ab}}$ & $76.6^{\mathrm{a}}$ & $11.1^{\mathrm{fgh}}$ & $9.59^{\mathrm{a}}$ \\
\hline \multicolumn{7}{|l|}{ Year } \\
\hline $2009 / 10$ & $65.8^{\mathrm{a}}$ & $102.7 \mathrm{~b}$ & $39.0^{c}$ & $71.3^{c}$ & $11.8^{\mathrm{a}}$ & $8.13^{c}$ \\
\hline $2010 / 11$ & $5.9 \mathrm{c}$ & $107.9^{a}$ & $41.1^{\mathrm{b}}$ & $76.2^{\mathrm{b}}$ & $11.3^{\mathrm{b}}$ & $10.06^{a}$ \\
\hline $2011 / 12$ & $12.5^{\mathrm{b}}$ & $92.1^{\mathrm{c}}$ & $42.3^{\mathrm{a}}$ & $77.3^{a}$ & $10.8^{c}$ & $8.57 \mathrm{~b}$ \\
\hline Average & 28.1 & 100.9 & 40.8 & 74.9 & 11.3 & 8.92 \\
\hline
\end{tabular}

Different letters indicate significant difference at $\mathrm{P}<0.05$ level.

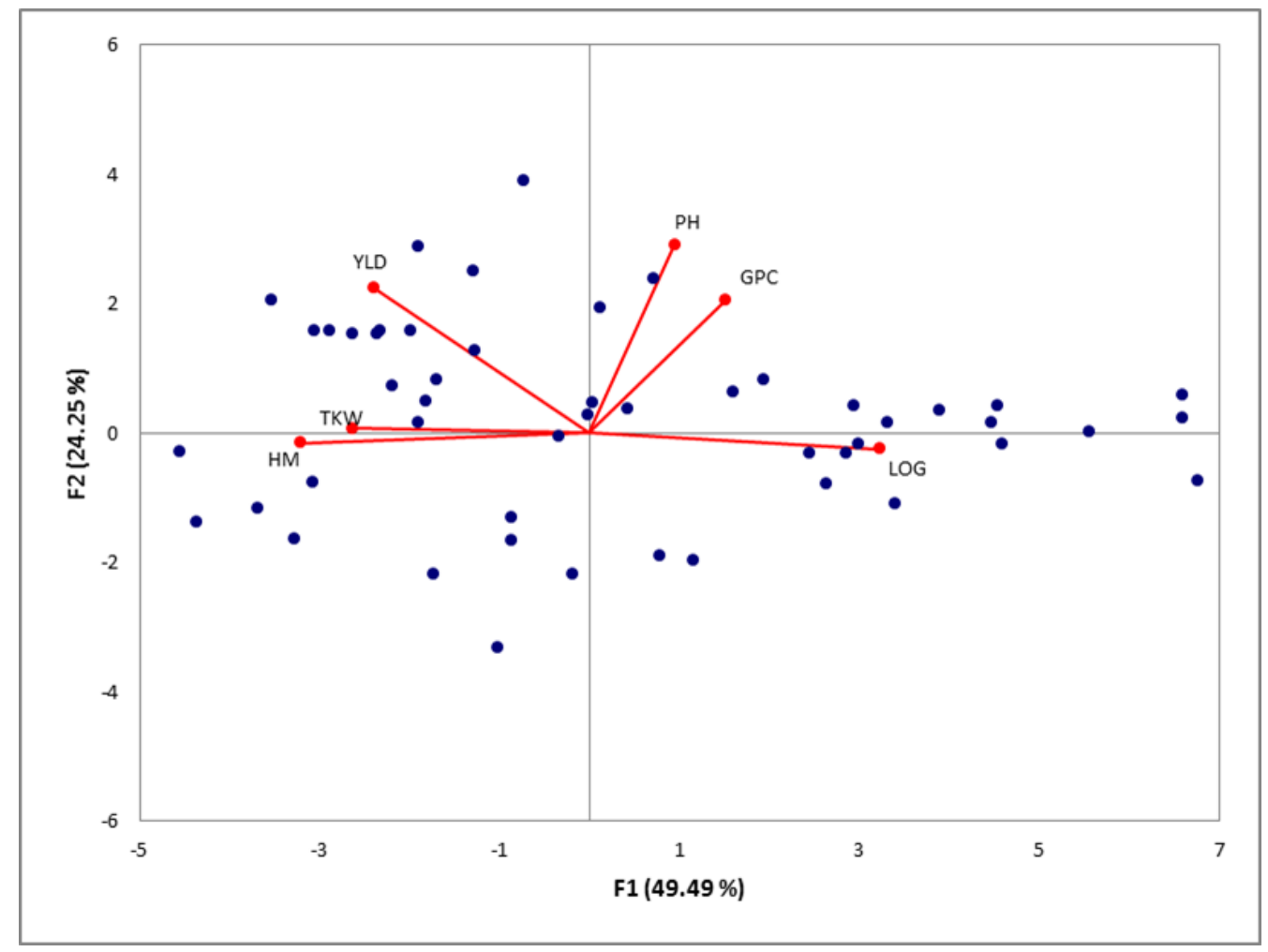

Figure 1. PCA analysis of trait relationship (lodging - LOG. plant height - PH. thousand kernel weight - TKW. hectolitre mass - HM. grain protein content -GPC and grain yield - YLD) in winter barley across three growing seasons 
The biplot of the principal component analysis illustrates relationships between the studied barley traits for all three growing seasons pooled together (Fig. 1). First PCA explained $49.5 \%$ of total variation, while second PCA explained $24.5 \%$. Together, both axes accounted for $73.7 \%$ of the total variation in the data. According to the biplot, PCA1 relates predominantly to TKW, HM and LOG, while PH was mostly related to PCA2.

YLD is one of the most important and complex traits in cereal breeding and its continuous improvement remain the top priority during the development of new varieties worldwide (Yan et al. 2007). YLD depends upon a combination of different yield components and plant traits, such as TKW, HM, PH, LOG (Pržulj et al. 2014). Therefore it is important to reveal relationship of these traits and YLD. Moreover, the identification of important traits for selection and the phenotypic expresion of desired traits are also essential for the development of the two-rowed winter malting barley ideotype.

According to Figure 1, YLD had a positive relationship with TKW and HM. On the other hand, Deniz et al. (2009) reported that TKW had negative direct effect on barley grain yield. TKW was negatively associated with GPC. Similarly, Pržulj \& Momčilović (2008) reported significant negative correlation between these two traits. Since high protein level result in unacceptable malt quality (Chen et al. 2006), malting barley breeding programs should focus on the selection of genotypes with increased TKW.

PCA showed that YLD had no relationship with $\mathrm{PH}$. The absence of relationship between YLD and $\mathrm{PH}$ can be explained by the observation that taller plants potentially have an increased capacity to store assimilates in vegetative organs for the retranslocation to grains during grain filling period (Slafer et al. 1996), however these plants are more susceptible to lodging, leading to decreased yield (Inostroza et al. 2009).

Breeding for lodging resistance represents an important goal during the development of new varieties, since susceptibility to lodging often results in yield and quality reduction (Jedel \& Helm 1991). LOG had a strong negative relationship with YLD, HM and TKW. Thus, genotypes susceptible to lodging had low yielding potential and should be excluded from breeding trials (Fig. 1). In agreement with this study, Pearson et al. (1989) and Berry et al. (2004) showed that besides the significant grain yield loss, LOG reduces grain HM, TKW, percent plump kernels, kernel numbers and increased percentage of thin kernels. Further, Jadel \& Helm (1991) reported that barley YLD loss depends from the growth stage when LOG occurred. Lodging before grain filling results in partial seed development, while lodging at maturity disables mechanized harvest and exposes plants to disease attack. Since factors that cause lodging may occur at different stages of plant development in different seasons, it is difficult to develop lodging resistant cultivars in field (Pržulj \& Momčilović 2012).

\section{Conclusions}

This study showed significant effects of $Y, G$ and $G \times Y$ interaction on barley yield and other agronomic traits. Three genotypes, G10, G19 and G4, can be distinguished because of their increased TKW and high yield potential. Biplot analysis revealed positive relationship between grain yield and TKW and HM, while LOG and grain yield were negatively associated. Conducted experimentation shows that the grain yield increase in winter two-rowed malting barley can be achieved by selecting plants with optimized/indifferent plant height more resistant to lodging with higher TW (above $41.0 \mathrm{~g}$ ), lower GPC (about $11.0 \mathrm{~g} 100^{-1} \mathrm{~g} \mathrm{dm}$ ) and also by acknowledging analogous connection to cytolytic and proteolytic malt degradation. Also, selection should be directed against plant lodging.

\section{References}

Berry, P.M., Sterling M., Spink J.H., Baker C.J., Sylvester-Bradley R., Mooney S.J., Tams A.R., \& Ennos A.R. (2004). Understanding and reducing lodging in cereals. Advances in Agronomy 84: 218-263.

Chen, J.X., Dai, F., Wei, K., \& Zhang, G.P. (2006). Relationship between malt qualities and $\beta$-amylase activity and protein content as affected by timing of nitrogen fertilizer application. Journal of Zhejiang University Science B 7(1): 79-84.

Deniz, B., Kavurmaci, Z., \& Topal, M. (2009). Determination of ontogenetic selection criteria for grain yield in spring barley (Hordeum vulgare) by path-coefficient analysis. African Journal of Biotechnology 8: 2616-2622.

Eticha, F., Grausgruber, H., \& Berghoffer, E. (2010). Multivariate analysis of agronomic and quality traits of hull-less spring barley (Hordeum vulgare L.). Journal of Plant Breeding and Crop Science 2(5): 81-95.

Falconer, D.S., \& Mackay ,T.F.C. (1966). Introduction to Quantitative Genetics. 4th edition, Longman, New York, p. $132-133$.

FAOSTAT (2014): Food and Agriculture Organization (FAO). FAOSTAT.(Available at http:// faostat.fao.org)

Fox, G.P., Kelly, A.M., Poulsen, D.M.E., Inkerman, P.A., \& Henry, R.J. (2006). Genetic and environmental effects on selecting improved barley grain size in dry environments. Journal of Cereal Science 43: 198-208.

Fox, G.P., Nguyen, L., Bowman, J., Poulsen, D.M.E., Inkerman, A., \& Henry, R.J. (2007). Relationship between hardness genes and quality in barley (Hordeum vulgare). Journal of the Institute of Brewing 113: 87-95.

Gholipoor, M., Rohani, A., \& Torani, S. (2013). Optimization of traits to increasing barley grain yield using an artificial neural network. International Journal of Plant Production 7(1): 118.

Inostroza, L., Del Pozo, A., Matus, I., MacHado, S., \& Corey, A. (2009). Association mapping of plant height, yield, and yield stability in recombinant chromosome substitution lines (RCSLs) using Hordeum vulgare subsp. spontaneum as a source of donor alleles in a Hordeum vulgare subsp. vulgare background. Molecular Breeding 23(3): 365-376. 
Jedel, P.E., \& Helm, J.H. (1991). Lodging effects on a semidwarf and two standard barley cultivars. Agronomy Journal 83: 158161.

Kamara, A.Y., Kling, J.G., Menkir, A., \& Ibikunle, O. (2003). Agronomic performance of maize (Zea mays L.) breeding lines derived from low nitrogen maize population. The Journal of Agricultural Science 141: 221-230.

Mladenov, V., Banjac, B., Krishna, A., \& Milošević, M. (2012). Relation of grain protein content and some agronomic traits in European cultivars of winter wheat. Cereal Research Communications 40 (4): 532-541

Olesen, J.E., Trnka ,M., Kersebaum, K.C., Skjelvag, A.O., Seguin, B., Peltonen-Sainio P., Rossi, F., Kozyra, J., \& Micale, F. (2011). Impacts and adaptation of European crop production systems to climate change. European Journal of Agronomy 34: 96112.

Pearson, C.H., Golus, H.M., \& Tindal, T.A. (1989). Ethephon application and nitrogen fertilization of irrigated winter barley in an arid environment. Agronomy Journal 81: 717-719.

Pettersson, C.G., \& Eckersten, H. (2007). Prediction of grain protein in spring malting barley grown in northern Europe. European Journal of Agronomy 27(2-4): 205-214.

Pržulj, N., \& Momčilović, V. (2008). Characteristics of Malting Barley in Southeast Europe. I. Spring barley. In: Ceccarelli, S., Grando, S. (Eds.) Proceedings of the 10th International Barley Genetics Symposium. 5-10 April 2008. Alexandria. Egypt. ICARDA. PO Box 5466. Aleppo, Syria, 484-494.

Pržuli, N., Momčilović, V., Nožinić, M., Jestrović, Z., Pavlović, M., \& Orbović, B. (2010). Importance and breeding of barley and oats. Ratar. Povrt. 47(1): 33-42.

Pržulj, N., \& Momčilović, V. (2012). Spring barley performances in the Pannonian zone. Genetika 44(3): 499-512.

Pržulj, N., Momčilović, V., Simić, J., \& Mirosavljević, M. (2014). Effect of growing season and variety on quality of spring two -rowed barley. Genetika 46: 59-73.

Rasmusson, D.C. (1987): An evaluation of ideotype breeding. Crop Science (27)6: 1140-1146.
Savin, R., \& Molina-Cano, J.L. (2002). Changes in malting quality and its determinants in response to abiotic stresses. In: Slafer, G.A., Molina-Cano, J.L., Savin, R., Araus, J.L., Romagosa, I. (Eds.). Barley science- recent advances from molecular biology to agronomy of yield and quality. Food Products Press. New York, USA. 523-550.

Slafer, G.A., Calderini, D.F., \& Miralles, D.J. (1996). Yield components and compensation in wheat: opportunities for further increasing yield potential. In: Reynolds, M.P. Rajaram, S., McNab, A. (Eds.) Increasing Yield Potential in Wheat: Breaking the Barriers. Mexico DF, CIMMYT. 101134

StatSoft. Inc. (2011). STATISTICA (data analysis software system). version 10 (www.statsoft.com)

Steel, R.G.D., \& Torrie, J.H. (1980). Principles and procedures of statistics: a biometrical approach. Chapter 8 . second edition. McGraw-Hill. Book Company. New York. USA. 172-191.

Wright, L. (2000). Malting barley for the new Millennium. In Vivar, H.E., McNab, A. (Eds.) Barley breeding for the new Millennium. Proceedings of an international symposium. CIMMYT. Mexico. 28-33.

Yan, W., \& Kang, M.S. (2003). GGE biplot analysis: A graphical tool for breeders, geneticists and agronomists. CRC Press. Boca Raton. FL. USA

Yan, W., Molnar, S., Fregeau-Reid, J., McElroy, A., \& Tinker, N.A. (2007). Associations among oat traits and their responses to the environment in North America. Journal of Crop Improvement 20: $1-29$.

Yuen, S.H., \& Pollard, A.G. (1953). Determination of nitrogen in soil and plant materials: use of boric acid in the microKjeldahl method. Journal of the Science of Food and Agriculture 4: 490-496.

Žáková, M., \& Benková, M. (2006). Characterization of spring barley accessions based on multivariate analysis. Communications in Biometry and Crop Science 1(2): 124-134.

\section{Povezanost između prinosa zrna i agronomskih osobina ozimog pivskog ječma}

\section{Milan Mirosavljević · Novo Pržulj • Petar Čanak · Vojislava Momčilović · Vladimir Aćin · Bojan Jocković · Nikola Hristov • Novica Mladenov}

Sažetak: Prinos zrna je jedna je od najznačajnijih i najsloženijih osobina u procesu oplemenjivanja strnih žita koja zavisi od većeg broja svojstava biljaka. Uspešni programi oplemenjivanja zahtevaju pravilno poznavanje povezanosti između prinosa i različitih agronomskih osobina. Cilj ovog ispitivanja je bila ocena genotipova ozimog pivskog ječma i asocijacija između pojedinih agronomskih osobina i prinosa zrna. PCA biplot analiza je korištena za proučavanja povezanosti između poleganja, visine, mase hiljadu zrna, hektolitarske mase, sadržaja proteina i prinosa zrna kod 19 genotipova ječma. Rezultati su pokazali značajan uticaj godine, genotipa i interakcije genotip-godina na ispitivane osobine ječma. Takođe, utvrđeno je da se prinos zrna ozimog pivskog ječma može unaprediti odabirom biljaka optimizovane visine otpornih na poleganje sa višom masom hiljadu zrna

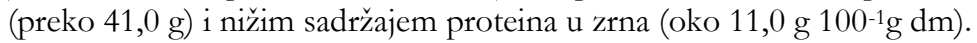

Ključne reči: agronomske osobine, biplot, genotip, Hordeum vulgare, ječam, kvalitet, PCA, prinos zrna 